\title{
The Cultivating Strategy of Internationalized Professional Teachers in the Sino-Foreign Cooperative Education of Higher Vocational Colleges
}

\author{
Zhan-jiu WANG \\ Ningbo City College of Vocational Technology, Ningbo, China
}

\begin{abstract}
Keywords: Higher Vocational Colleges; Sino-Foreign Cooperative Education; Internationalized Professional Teachers; Cultivating Strategy.
\end{abstract}

\begin{abstract}
The biggest difficulty of the Sino-foreign cooperative education of higher vocational colleges lies in short of internationalized professional teachers. In order to guarantee the teaching quality of the Sino-foreign cooperative education, it is necessary to cultivate sufficient professional teachers, who are possessed of international views and competent in the development of the Sino-foreign cooperative education of higher vocational colleges.
\end{abstract}

\section{Introduction}

Nowadays the integration of economic development is one of the most important trends of the development of the world's economy, in which the economic activities in the world have gone beyond the national borders and they have already become an organic economic unity all over the world by means of international trade, technology transfer, capital flow, service outsourcing and mutual dependence for existence. As a result, Chinese economy has blended into the mainstream of the integration of world's economy and industry chains. As an important part in the higher education of China, higher vocational colleges must keep pace with the integration of economic development in the world, and carry out the developing strategy of educational internationalization. Meanwhile higher vocational colleges also must positively introduce foreign high quality education resources and advanced teaching ideas to develop innovative personnel cultivating mode so that international talents can be cultivated, who are possessed of intercultural communication competence.

In recent years, many higher vocational colleges have made many Sino-foreign cooperative education projects, and introduced foreign high quality education resources and advanced teaching ideas to promote their educational internationalization level, aiming at cultivating the talents with broad international views and intercultural communication competence, so as to meet the demand that Chinese economy can be merged into the development of the integration of world's economy and that the strategy of the China-proposed Belt and Road initiative can be implemented. However, it is obvious that the biggest difficulty of the Sino-foreign cooperative education of higher vocational colleges lies in short of internationalized professional teachers, and hence it is critical how the higher vocational colleges can succeed cultivating competent internationalized professional teachers for the Sino-foreign cooperative education projects.

The Composition and the Orientation as well as the Requirement of the Team of Internationalized Professional Teachers of the Sino-Foreign Cooperative Education of Higher Vocational Colleges

\section{The Composition of the Team of Internationalized Professional Teachers of the Sino-Foreign Cooperative Education of Higher Vocational Colleges}

The length of schooling amounts to three years for the international major of Sino-foreign cooperative education of higher vocational colleges, during which there are six semesters. "3+0"Single Campus cultivating mode is popular for the most Sino-foreign cooperative education projects, that is if the students can complete the credits of the courses required by Sino-foreign cooperative colleges in Chinese campus in three years, they can graduate and be awarded the diplomas by both Sino-foreign cooperative colleges. Foreign languages course are usually arranged 
from the first to the second semester in order to strengthen and improve students' foreign language level so that they can learn the professional courses of foreign cooperative college after one-year-strengthened training of foreign language. Meanwhile the students also learn some basic courses required by Chinese cooperative college during this academic year. From the third to the fifth semester, the students focus on the specialized courses required by Sino-foreign cooperative colleges. And during the sixth semester, the students are required to finish a four-month internship and fulfill the tasks of graduation practice.

The team of internationalized professional teachers of the Sino-foreign cooperative education usually is made up of professional teachers of Sino-foreign cooperative college and administrative staff for teaching and students. The teachers of Chinese cooperative college include full-time teachers and part-time teachers whereas the teachers of foreign cooperative college include the teachers coming from the foreign cooperative college as well as the international teachers hired by the foreign cooperative college.

\section{The Orientation and the Requirement of Internationalized Professional Teachers of the Sino-Foreign Cooperative Education of Higher Vocational Colleges}

The orientation of internationalized professional teachers of the Sino-foreign cooperative education of higher vocational colleges is to undertake the teaching duty in Sino-foreign cooperative education project and cultivate the talents with broad international views and intercultural communication competence. And therefore Sino-foreign cooperative majors are in need of sufficient, stable and competent teachers, who conform to the standards for the development of Sino-foreign cooperative majors to ensure that the teaching tasks of Sino-foreign cooperative majors can be fulfilled accordingly. The requirements of internationalized professional teachers of the Sino-foreign cooperative education of higher vocational colleges are as follows:

Firstly, they are required to have the capacities of teaching in the Sino-foreign cooperative education project and they must run up to the teaching qualification of the Sino-foreign cooperative education project. In other words, the foreign teachers must accord with the qualification required by State Bureau of Foreign Exports Affairs of China and the Sino-foreign cooperative major while local Chinese teachers must measure up to the qualification required by the foreign cooperative college. Secondly, both local Chinese teachers and foreign teachers should have such qualities: performing the duty earnestly, loving their jobs, being well-behaved teachers, working hard, cultural inclusion and getting along well with the students. Thirdly, they must be familiar with international teaching mode of the Sino-foreign cooperative major, teaching methods and the ways of assessment.

\section{The Main Problems in the Sino-Foreign Cooperative Education of Higher Vocational Colleges}

The first problem in the Sino-foreign cooperative education of higher vocational colleges is the shortage of both local Chinese teachers and also foreign teachers, who are possessed of broadly international views, excellent teaching abilities and rich teaching experiences. On the other hand, in the operation of Sino-foreign cooperative education projects, some foreign teachers have less recognition of Chinese culture, so that they are not familiar with Chinese students' learning ways and underestimate the difficulties for Chinese students to learn specialized courses of foreign cooperative college in foreign language. And even some foreign teachers don't come from foreign cooperative college and they are just hired to teach in China by the foreign cooperative college, so those foreign teachers can't stay long to teach in China, so there are too frequent rotations of foreign teachers. In contrast, though many local Chinese teachers have oversea education background, they have less teaching experiences in Sino-foreign cooperative education projects and they usually have low professional titles, so that they don't fully master teaching criteria, teaching mode, teaching methods and assessment styles of the specialized courses of foreign cooperative college. Lastly, in the process of teaching specialized course of foreign college, foreign teachers teach them in foreign language, while local Chinese teach those courses both in Chinese and foreign language, so it is very difficult for local Chinese teachers to perform in the same way as foreign teachers do in terms 
of teaching ideas, teaching methods and assessment. For another, in teaching foreign language, foreign teachers are in charge of listening and speaking, while local Chinese teachers are responsible for reading and writing of foreign language, and as a result, local Chinese teachers and foreign teachers sometimes can't agree on the teaching criteria, teaching requirement and assessment on the foreign language teaching.

\section{The Effective Strategy to Cultivate Internationalized Professional Teachers of the Sino-Foreign Cooperative Education of Higher Vocational Colleges}

In order to guarantee the successful operation and continuous improvement of teaching quality of the Sino-foreign cooperative education projects, it is necessary to cultivate sufficient internationalized professional teachers, who are more stable and up to the qualifications required in the development of the Sino-foreign cooperative education of higher vocational colleges. According to the major problems in the Sino-foreign cooperative education of higher vocational colleges, systematic training for the specialized teachers must be strengthened to make them qualified for the development of the Sino-foreign cooperative education, so as to guarantee the teaching quality of the Sino-foreign cooperative education. The effective strategies to cultivate internationalized professional teachers include the following aspects in the Sino-foreign cooperative education of higher vocational colleges.

\section{The Cultivating Strategies of Different Specialized Trainings are Separately Implemented to the Local Chinese Teachers and Foreign Teachers}

In the Sino-foreign cooperative education of higher vocational colleges, local Chinese teachers usually undertake two-thirds specialized courses of foreign cooperative college and most course of foreign language, as well as all the specialized courses of Chinese college, whereas foreign teachers are required to teach one-third specialized courses of foreign cooperative college and a small amount of courses of foreign language. On the basis of different educational backgrounds, different teaching experiences of local Chinese teachers and foreign teachers, as well as the practical operation of the Sino-foreign cooperative education projects, it is necessary to carry out different cultivating strategies of specialized trainings separately to the local Chinese teachers and foreign teachers to ensure successful operation and continuous improvement of the Sino-foreign cooperative education. First, the training of local Chinese teachers focus on acquiring the qualification of teaching specialized courses of foreign college, having a good grasp of teaching system, teaching modes and methods, and ways of assessment of specialized courses of foreign cooperative college, as well as improving foreign language level. As for the foreign teachers, the emphasis of their training lies in their understanding and knowing the administrative rules and requirement of teaching, Chinese students' cognitive behaviors and characteristics, culture of Chinese campus as well as living environment.

\section{The Cultivating Strategies Combined Training at Home with Training Abroad for the Local Chinese Teachers}

Local Chinese teachers are the main force of teaching, for they usually undertake two-thirds specialized courses of foreign cooperative college, and hence how to cultivate local Chinese teachers are more important in order to guarantee the teaching quality of the Sino-foreign cooperative education. There are some advantages to train local Chinese teachers at home. It is easy to gather local Chinese teachers together for training, and training can be carried out in a short time. In addition, foreign teaching experts can be hired to train local Chinese teachers, in which training can focus on acquiring the qualification of teaching specialized courses of foreign college, knowing well teaching system, teaching modes and methods, and requirement of assessment of specialized courses of foreign cooperative college. For instance, in the cooperation with Australian TAFE College, Chinese higher vocational colleges can employ Australian teaching experts to train local Chinese teachers for four to five weeks to acquire its Certificate IV in Teaching and Assessment, and at the sometime local Chinese become familiar with Australian TAFE teaching system, teaching 
modes and methods, as well as the ways of assessment. On the other hand, it is also necessary to send local Chinese teachers to the foreign cooperative college for training for a longer time, such as half a year, which can make local Chinese teachers to fully master systematic teaching modes and methods, as well as assessment ways and requirement. As a result, local Chinese teachers can improve their teaching abilities and also their commutative capabilities in foreign language quickly.

\section{The Cultivating Strategy Combined Holding Teaching Research Seminar by Local Chinese Teachers and Holding Teaching Research Seminar by both Local Chinese Teachers and Foreign Teachers at Regular Intervals}

It is an important and effective cultivating strategy to hold regular teaching research seminars in the cultivation of Chinese teachers and foreign teachers of Sino-foreign cooperative education projects. First, in the regular teaching research seminars, teachers can discuss the key point and difficult aspect of teaching contents about the courses in the Sino-foreign cooperative education projects, determine and inspect teaching process, utilize others effective teaching methods, and exchange the problems in teaching and their solutions. Secondly, teachers can also discuss and determine the detailed requirement and assessment methods of the specialized course of Sino-foreign cooperative major, standardize the teaching activities, and strictly implement teaching plans. In addition, in the teaching research seminar, local Chinese teachers and foreign teachers can exchange and analyze students' studying normal data, evaluate students' demand, determine reasonable teaching activities, improve teaching environment, and carry out course reforms in order to meet the demand for students' development. At last, teaching research seminars can be held differently by the local Chinese teachers, and by the local Chinese teachers and foreign teachers. It is proper to hold teaching research seminars by the local Chinese teachers once a week, while it is good to hold teaching research seminars by the local Chinese teachers and foreign teachers once two weeks.

During the teaching research seminars, local Chinese teachers and foreign teachers can exchange teaching information and learn from each other, and they can accumulate teaching experiences, know students' requirement, the methods to improve their teaching and find out the solutions to the teaching problems, which can promote teachers' teaching capacities and teaching quality can be guaranteed in the end.

\section{The Cultivating Strategy of Encouraging Specialized Teachers to Take Part in Teaching and Scientific Research Activities}

The teachers can improve their scientific research and teaching levels, as well as can broaden their academic visions, so it is a very important cultivating strategy to encourage the teachers to take part in the teaching and scientific research activities. And the plans should be made to award the teachers to apply for the teaching and scientific research projects and publish academic papers. Meanwhile, specialized teachers of the Sino-foreign cooperative education should be encouraged to take part in academic conferences so as to broaden their academic visions. For example, specialized teachers of the Sino-foreign cooperative education can apply for the research items about teaching design modes, teaching quality guarantee system of the Sino-foreign cooperative education projects and so on. The teachers can effectively promote their teaching abilities and academic research levels by means of their teaching and scientific research items as well as the publications of their papers.

\section{Making Pairs between the Apprentice and the Master is an Effective Cultivating Strategy for Specialized Teachers of the Sino-Foreign Cooperative Major}

In the cultivations of specialized teachers of the Sino-foreign cooperative major, making pairs between the apprentice and the master is an effective cultivating strategy. The master, senior teacher with higher academic title, has abound teaching experiences and strong scientific research abilities, while the apprentice, young teacher with low academic title, are short of teaching experiences and has weak scientific research abilities. And therefore, the senior teacher with higher academic title can be assigned to make pairs with the young teacher and they are in the master-apprentice relation, so that the master can help the apprentice with teaching and scientific research, which can benefit 
the growth of young teachers.

Firstly, the apprentice and the master can prepare lessons together, during which the master can guide the apprentice in terms of detailing teaching contents, the problems in teaching and their solutions, and the assessment about students' learning. What's more, the master can have visits to the apprentice's class to guide his teaching, and meanwhile, the master can also instruct the apprentice to take part in teaching and scientific research and publish academic papers to promote the young teacher's teaching and scientific research levels. On the other hand, the apprentice also can go to the master's class for observation learning and learn effective teaching methods so as to improve his teaching abilities.

\section{It is an Effective Cultivating Strategy of Specialized Teachers to Build a Complete Teaching Supervision System in the Sino-Foreign Cooperative Education}

To build a complete teaching supervision system is an important measure for guaranteeing teaching quality of the Sino-foreign cooperative major, which can promote teachers' development of the Sino-foreign cooperative major and improve their professional standards and teaching abilities. The teaching supervisors are usually the senior teachers with higher academic titles or teaching experts, who both have rich teaching experiences, with high academic achievements and strong duties and are fair and just in handling affairs. The team of teaching supervisors is often made up of Chinese teaching supervisors and foreign teaching supervisors, and meanwhile foreign teaching supervisors are usually adjunct head of the major in honor of foreign cooperative college. There are two roles for the teaching supervision in the Sino-foreign cooperative major. One role is to supervise teaching while another is to guide teaching. In the teaching supervision, supervisors will inspect and examine teachers' teaching design, teaching methods and teaching assessment by means of random visit for observation, the forums of teachers or students, checking teaching materials. Teaching supervisors also evaluate teachers' teaching and find out the problems in teaching, and put forward their suggestions for the improvement. On the other hand, teaching supervisors can guide teachers by providing teachers with feedback information of weak points and advices for the improvement, and urging the teachers to learn advanced teaching ideas. In short, the teachers of the Sino-foreign cooperative major can improve their teaching integration capabilities by teaching supervision.

\section{Conclusion}

In the teaching system of the Sino-foreign cooperative major, teachers are teaching designers, instructors of specialized knowledge and skills, the organizers of teaching activities and the administrator of teaching in class, and play a dominant role in teaching. And therefore, it is critical to set up a team of sufficient competent specialized teachers with broad international visions and strong duties in order to guarantee teaching quality the Sino-foreign cooperative education projects. But the biggest difficulty of the Sino-foreign cooperative education of higher vocational colleges lies in short of internationalized professional teachers, so we must attach great importance to the cultivation of specialized teachers for the of the Sino-foreign cooperative education of higher vocational colleges. There are many effective cultivating strategies of internationalized professional teachers in the Sino-foreign cooperative education of higher vocational colleges.

\section{References}

[1] Yin Ping. The Analysis of the Cultivating Teachers in the Sino-foreign Cooperative Education of Higher Vocational Colleges [J]. Journal of Educational Institute of Suzhou City, 2010, Vol.27 (3), PP. 93-95.

[2] Wang Zhan-jiu. The Effective Approach to Cultivate Internationalized High-skilled Talents of Higher Vocational Colleges in Ningbo City [J]. Communication of Vocational Education, 2014, Vol. 336 (5), PP. 15-18. 